\title{
ILUMINAÇÃO CÊNICA E DESOBEDIÊNCIAS DE GÊNERO
}

\author{
AUTOR: VINICIUS SANTOS SOUZA \\ CO-AUTOR/ORIENTADOR: DODI TAVARES BORGES LEAL
}

Resumo: Quando uma Gota Trava - reflete sobre as experiências metodológicas a partir da teatra da oprimida, e da iluminação cênica como instrumento para a desobediência de gênero, tendo a esquete Gota Trava como mediadora desse processo, tecendo relações com a transgédia e as possibilidades de adaptação expandida. A partir das nossas experiências e processos de construção da produção que foi apresentada enquanto esquete durante a Mostra Internacional de Teatro de São Paulo, a MITsp 2020, sob curadoria da Profa. Dra. Dodi Tavares Borges Leal noevento "Encontra de Pedagogias da Teatra: afetividades do saber riscar e arriscar", no quadro do eixo Ações Pedagógicas. Gota Trava tem início a partir de um desejo pessoal de investigar a possibilidades de remontagem de um texto clássico, ao encontrar Medéia de Eurípedes, e a sua adaptação brasileira, Gota D'água junto com Caz Ângela, que atuou como atriz e dramaturga, passamos a investigar a possibilidade da existência de uma transcestralidade nessas obras. Ainda que em ambas não se nomeie a presença de pessoas trans, passamos a buscar os fragmentos do texto, imagens e potências que ainda que indiretamente dialogassem com as existências e processos de vida, resiliência e contra-ataque que constituem as experiências diárias de pessoas trans. Em nosso processo de investigação cênica iniciamos com leituras, análises e recortes de passagens de ambos os textos, tecendo uma adaptação expandida que não seguia a obrigação de apenas remontar as obras, mas sim, de constituir um novo clássico, que inscreva na história corpos trans, compondo com fragmentos das experiências e memórias da Caz Ângela, inventando uma nova personagem trágica, parida de Medéia, Joana e de Caz Ângela Arruda Apolinario Rodrigues.

Palavras-chave: Teatra da oprimida, desobediência de gênero, iluminação cênica. 